\title{
Interaction between Kisspetin and Dopamine in the Regulation of in vitro LH Release in Prussian carp (Carassius gibelio Bloch, 1782) Females at the Time of Gonad Recrudescence and Spawning Period
}

\author{
Mirosława Sokołowska-Mikołajczyk ${ }^{1, *}$ (D), Grzegorz Gosiewski ${ }^{1}$, Jarosław Chyb ${ }^{1}$, \\ Magdalena Socha ${ }^{1}$
}

${ }^{1}$ Department of Ichthyobiology and Fisheries, University of Agriculture, ul. Prof. T. Spiczakowa 6, 30-199 KrakowMydlniki, Poland.

\section{Article History \\ Received 30 October 2017 \\ Accepted 22 August 2019 \\ First Online 16 September 2019 \\ Corresponding Author \\ Tel.: +48126375176 \\ E-mail: msokmik@ar.krakow.pl}

\section{Keywords}

Dopamine

Human kisspeptin

LH

Prussian carp

\begin{abstract}
The aim of the present study was to demonstrate the in vitro response (LH release) of Prussian carp pituitary cells to mammalian kisspeptin in static incubations. Pituitary glands were collected at two periods of the season (at the time of gonad recrudescence or spawning period) from untreated fish or those with dopaminergic system blocked in vivo by injection of pimozide - a dopamine receptor antagonist. $\mathrm{LH}$ measurement (by ELISA method) have shown that there was no significant impact of kisspeptin on the level of this gonadotropin at both investigated seasons of the year if pituitary glands for the study were collected from untreated females. In case of fish pre-treated with pimozide there was a significant stimulation of LH release in both investigated seasons. The results demonstrate the direct effect of kisspeptin on $\mathrm{LH}$ release from the Prussian carp gonadotropic cells, dependent on the strength of dopamine inhibition on $\mathrm{LH}$ secretion.
\end{abstract}

\section{Introduction}

Presently a great number of neuropeptides and neurotransmitters of brain origin have been shown to affect pituitary gonadotropic activity in fish. Some of them have a proven functional significance, mainly gonadoliberin ( $\mathrm{GnRH}$ ) and dopamine (DA). The use of superactive $\mathrm{GnRH}$ analogues to synchronize or to stimulate the last phases of gonad maturation ovulation and spermiation - is a common practice in aquaculture of many economically important species (Mylonas, Fostier, \& Zanuy, 2010). The analogues of GnRH combined with dopamine antagonists (pimozide, domperidone, metoclopramide) significantly improve the effectiveness of hormonal treatment (Yaron, 1995; Brzuska, 2001; Mikolajczyk et al., 2003; Arabaci \& Sari, 2004). In some species such hormonal treatment is less effective, because the inhibitory strength of dopamine at the time of final maturation is less pronounced, like in salmonid fish (Vacher, Mañanos, Breton, Marmignon, \& Saligaut, 2000; Vacher, Ferrière, Marmignon, Pellegrini, \& Saligaut, 2002; Levavi-Sivan, Bogerd, Mañanós, Gómez, \& Lareyre, 2010) or does not exist, like in Atlantic croaker Micropogonias undulatus (Copeland \& Thomas, 1989) or gilthead sea bream, Sparus aurata (Zohar \& Mylonas, 2001).

In some species there are other key hormones involved in gonadotropin release control, like GABA, NPY (Kah et al., 1989b, 1992; Peng, Gallin, Peter, Blomqvist, \& Larhammar, 1994) and in such cases the application of hormones other than GnRH agonist together with dopamine antagonist could be more effective. The good candidate which could improve recently applied methods of hormonal control of reproduction are the naturally occurring substances like kisspeptins (kisspeptin1 and kisspeptin2) or its 
analogues, which seem to be the most important regulator of maturation and reproduction of vertebrates. Having quite conservative structure among vertebrates, kisspeptins could serve as this universal hormonal preparation controlling maturation of different fish species.

There are several fish species investigated to date and the knowledge of kisspeptin system includes the details on the anatomy, expression of kisspeptin genes and receptors, localization or distribution: tilapia, Oreochromis niloticus (Parhar, Ogawa, \& Sakuma, 2004), grey mullet, Mugil cephalus (Nocillado, Levavi-Sivan, Carrick, \& Elizur, 2007), cobia, Rachycentron canadum and Senegalese sole, Solea senegalensis (Mohammed, Benninghoff, Holt, \& Khan, 2007; Mechaly, Vińas, \& Piferrer, 2009). In medaka (Oryzias latipes) and zebrafish (Danio rerio) a novel gene Kiss2 was identified (Kitahashi, Ogawa, \& Parhar, 2009), which can play a role in reproductive as well as nonreproductive processes. Two different kisspeptin genes (Kiss1 and Kiss2) have been characterized in the zebrafish, Danio rerio (Shahjahan, Kitahashi, Ogawa \& Parhar, 2013), goldfish, Carassius auratus (Li et al., 2009) sea bass, Dicentrarchus labrax (Felip et al., 2009) and chub mackerel, Scomber japonicus (Selvaraj et al., 2010, 2012).

It was experimentally proven that administration of kisspeptin increases LH secretion in the following fish species: goldfish, Carassius auratus (Li et al., 2009), European sea bass, Dicentrarchus labrax (Felip et al., 2009), striped bass, Morone saxatilis (Zmora et al., 2012) and affects gonad maturity: accelerates gonadal development in basses of genus Morone (Beck, Fulle, Peatman McEntire, Darwish, \& Freeman, 2012), accelerates spermatogenesis in prepubertal male chub mackerel, Scomber japonicus (Selvaraj et al., 2013), stimulates gonadal development in pre-pubertal male yellowtail kingfish Seriola lalandi during the breeding and non-breeding season (Nocillado, Zohar, Biran, Levavi-Sivan \& Elizur, 2013). Before the trials with kisspeptins in commercial fish farms, the necessary basic research should be conducted in order to find the effective doses, timing, way of administration, delivery systems, time of the season for the specific fish species, the possible effects on the fertilisation process, hatching and the offspring. There are already interesting conclusions from the paper of Selvaraj et al. (2013) who found that subcutaneous application of kisspeptin-1 induces spermiation in sexually immature chub mackerel and that this treatment is more effective than $\mathrm{GnRH}$ analogue application. They suggest to use this peptide for other farmed fish.

Kissepeptin acting directly on $\mathrm{GnRH}$ neurons (Zohar, Munoz-Cueto, Elizur, \& Kah, 2010) and on gonadotropic cells in the pituitary (Chang, Mar, Wlasichuk, \& Wong, 2012) may also coordinate the information coming from other brain systems involved in the control of gonadotropin secretion, namely from dopaminergic system. The putative link between kisspeptin and dopamine is not unfounded, as in mammals it was already demonstrated that dopaminergic system is one of the target places for kisspeptin (Clarkson \& Herbison, 2011; Goodman et al. 2012; Ozawa, Sawai, Iwata, Takumi \& lijima, 2012). According to our knowledge there is no data showing the direct connections between kisspeptin and dopamine systems in fish brain.

Fish are seasonally reproducing animals which mature and spawn in the most advantageous, for the offspring survival, season of the year. Dopamine inhibiting GnRH secretion at the brain level or inhibiting the action of GnRH at the level of pituitary gland (Yu \& Peter, 1992) controls the release of gonadotropins, thus onset of puberty and the final maturity of gonads. At the brain level dopamine may also affect other than $\mathrm{GnRH}$ neurons and the kisspeptin neurons are vey likely to be one of its target. This hypothesis on the possible interaction of dopamine, kisspeptin and GnRH system cannot be yet verified, but the experiments described in this paper were carried out to demonstrate the in vitro response (LH release) of Prussian carp pituitary cells to mammalian kisspeptin. Pituitary glands for the experiments were collected at two periods of the season (at the time of gonad recrudescence or spawning period) from untreated fish or those with dopaminergic system blocked in vivo by injection of pimozide (dopamine antagonist).

\section{Materials and Methods}

Fish

Fish, Prussian carp (Carassius gibelio Bloch, 1782) were purchased from Experimental Fish Farm in Zator of Inland Fisheries Institute in Olsztyn and were kept in the outdoor ponds of the Fisheries Research Station of the Department of Ichthyobiology and Fisheries, University of Agriculture in Krakow, Poland. The experiments were approved by the First Local Ethical Committee on Animal Testing in Krakow (decisions: 90/2013, 91/2013).

In two consecutive years experiments were performed at the time of gonad recrudescence (February) or at the spawning season (June). Every season fish were collected from outdoor ponds and transferred to 300 liters volume flow-through glass basins, in which they were kept for two days for acclimatization. At the time of gonad recrudescence water temperature was kept at $12 \pm 1^{\circ} \mathrm{C}$ and simulated natural photoperiod Light:Dark (L:D) was 8:16 and at spawning season water temperature was kept at $20 \pm 1^{\circ} \mathrm{C}$ and simulated natural photoperiod L:D was 16:8.

Pituitary glands for the in vitro incubation of cells were collected from sexually mature, two-year-old females of Prussian carp (Carassius gibelio, Bloch 1782). Average body weight of fish was $105.88 \pm 30.78 \mathrm{~g}$. Gonad maturity was specified as a percentage of body weight (gonadosomatic index - GSI): at the time of gonad 
recrudescence and spawning season $4.30 \pm 2.06 \%$ and $15.96 \pm 3.47 \%$, respectively.

For the whole experiment 60 pituitary glands were used (30 in one year and another 30 in the consecutive year, as a repetition). Each year half of the fish were used at the time of gonad recrudescence and another half at the spawning season. In each season glands were obtained from 7 fish injected with saline or from 8 fish treated with pimozide - a dopamine receptor antagonist (Sigma Aldrich Co., USA), at 3 hours before decapitation. Pimozide was injected intraperitonealy at a dose of $5 \mathrm{mg} \mathrm{kg}^{-1}$ body weight.

\section{Culture Technique}

On the day of the experiment fish were anaesthetised with 2-phenoxy-ethanol (Merck, Germany) at $0.3 \mathrm{~mL} \mathrm{~L}^{-1}$ of water, killed by decapitation and the pituitary glands were collected and placed in sterile ice-cold medium (MEM-Eagle, Sigma-Aldrich, USA) buffered with $15 \mathrm{nM}$ Hepes (Sigma-Aldrich, USA) and $9 \mathrm{mM}$ sodium bicarbonate (P.O.Ch., Poland).

The enzymatic dispersion of the pituitary glands and the technique of cell culture were described in detail elsewhere (Mikolajczyk, Weil, Epler, \& Breton, 1990; Sokolowska-Mikolajczyk, Socha, Szczerbik, \& Epler, 2009). In brief, collected glands were chopped into small pieces and subjected to dispersion for 6-8 $\mathrm{h}$ at $20^{\circ} \mathrm{C}$ in the medium containing $0.1 \%(\mathrm{w} / \mathrm{v})$ collagenase $\mathrm{H}$ (Boehringer Mannheim, Germany) and 1\% BSA (Sigma-Aldrich, USA). The cells were harvested by 10 -min centrifugation $\left(200 \mathrm{~m} \mathrm{~s}^{-2}\right)$ at $20^{\circ} \mathrm{C}$ and washed twice with pre-incubation medium containing $2 \%(\mathrm{v} / \mathrm{v})$ serum substitute (Ultroser SF, Sepracor S.A., France) and $1 \%(\mathrm{v} / \mathrm{v})$ antibiotic-antimycotic (Sigma-Aldrich, USA). Cell viability test (trypan-blue test) and cell counting were performed with a Thoma haemocytometer and it was routinely better than $95 \%$. Cells were resuspended in the pre-incubation medium and transferred into four 96-well microplates (Nunc A/S Denmark) coated with Poly-L-lysine (Sigma-Aldrich, USA). Each well contained approximately $5 \times 10^{4}$ cells in $250 \mu \mathrm{L}$ of medium. Then the plates were sealed and incubated for $48 \mathrm{~h}$ at $22^{\circ} \mathrm{C}$. On the third day of culture the pre-incubation medium was replaced with medium containing kisspeptin (Metastin $45-54$ amide human, Sigma Aldrich Co., USA) at a concentrations of $10^{-9}, 10^{-8}, 10^{-7}$ or $10^{-6} \mathrm{M}$. Control wells were filled up with medium without any supplementation. Each treatment group consisted of five wells containing cells from the pool of pituitaries. For each variant in each experiment $n=5$. At the end of the incubation period ( 24 hours) the plates were centrifuged $\left(200 \mathrm{~m} \mathrm{~s}^{-2}\right)$ for $10 \mathrm{~min}$ at $20^{\circ} \mathrm{C}$ and the media were collected and frozen at $-20^{\circ} \mathrm{C}$ until $\mathrm{LH}$ determination by ELISA (Kah, Pontet, Nunez Rodriguez, Calas, \& Breton, 1989a). Sensitivity of the performed ELISA was in the range of $0.6-100 \mathrm{ng} \cdot \mathrm{mL}^{-1}$ with the intra- and inter-assay coefficients of variance at $5 \%$ and $9 \%$, respectively.

\section{Statistical Analysis}

LH concentrations were analysed using GraphPad Prism statistical software (version 5 GraphPad software, USA). LH levels in the experimental groups were normalized as a percentage of the control group values (without drug treatment) and then data were analysed using nonparametric two-tailed Mann-Whitney U-test with Bonferroni correction. The differences between the means were considered as significant for $P<0.05$. Data presented on the graphs (mean percentage of LH levels \pm SEM) come from two independent experiments.

\section{Results}

A. The effects of different concentrations of kisspeptin on LH levels in the incubation medium of pituitary cells at the time of gonad recrudescence:

a) pituitary cells of untreated fish (Figure $1 \mathrm{~A}$ )

Changes in LH levels in the media of pituitary cells incubated in the presence of kisspeptin at the concentration range from $10^{-9}$ to $10^{-6} \mathrm{M}$ were not significant in relation to the basal $\mathrm{LH}$ concentration (control media).

b) pituitary cells of fish treated with pimozide (Figure 1B)

Kisspeptin at the concentrations of $10^{-9}$ and $10^{-7} \mathrm{M}$ increased LH levels in the media by 45 and 40 percent, respectively. Other investigated concentrations of kisspeptin $\left(10^{-8}\right.$ and $\left.10^{-6} \mathrm{M}\right)$ did not cause any statistically significant changes.

B. The effects of different concentrations of kisspeptin on LH levels in the incubation medium of pituitary cells at the spawning season:

a) pituitary cells of untreated fish (Figure 2A)

Changes in $\mathrm{LH}$ levels observed in the incubation media containing the tested concentrations of kisspeptin were not statistically significant when compared with control incubations.

b) pituitary cells of fish treated with pimozide (Figure 2B)

All concentrations of kisspeptin (from $10^{-9}$ to $10^{-6}$ M) evoked almost the same, statistically significant increase of LH levels in the media (by 45, 42, 36 or 37 percent, respectively).

\section{Discussion}

Although there is no doubt about the role of kisspeptin in the control of the reproductive axis in vertebrates, there are still some discrepancies, if the site of its action is considered (Richard, Corvaisier, Camacho, \& Kottler, 2009). According to Gutierrez-Pascual et al. (2007), Yang, Jiang, Chan, Ko, \& Wong (2010) and Chang et al. (2012) kisspeptin acts both at the hypothalamic and pituitary levels. Li et al. (2009) did not observe a direct influence of both kisspeptins (Kiss1 and Kiss2) on LH secretion from goldfish pituitary cells. Yang et al. 

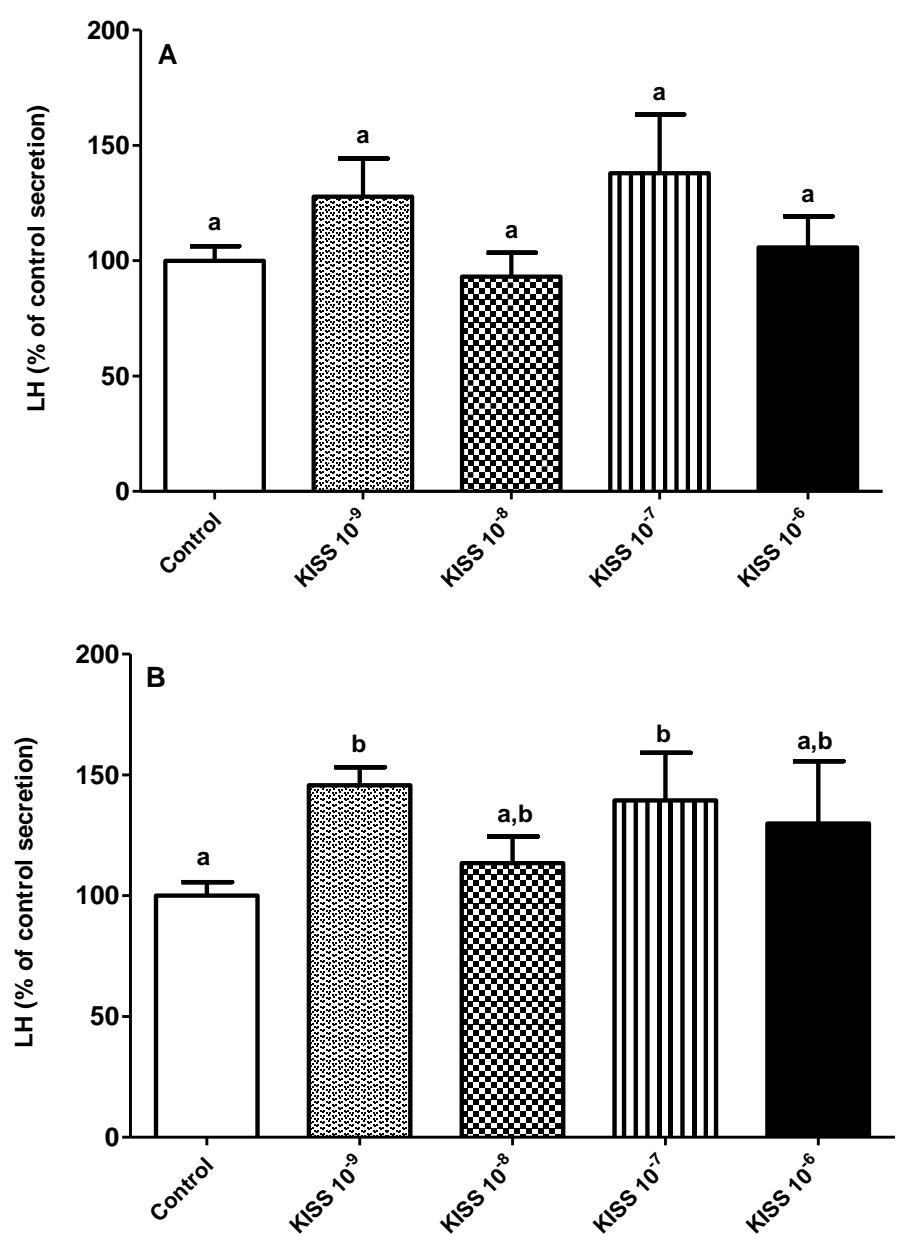

Figure 1. Percentage of control LH secretion from Prussian carp female pituitary cells harvested at the time of gonad recrudescence and incubated for $24 \mathrm{~h}$ with human kisspeptin at 10-9, 10-8, 10-7 or 10-6 M. (A) pituitary cells of control fish, (B) pituitary cells of fish pretreated with pimozide - a dopamine receptor antagonist 3 hours before cell harvesting. Bars represent means \pm SEM. Different letters of the alphabet identify significant differences between groups $(P<0.05$; Mann-Whitney $U$-test with Bonferroni correction). Data presented on the graphs (mean percentage of LH levels \pm SEM) come from two independent experiments.

(2010) were the first who demonstrated a direct effects of kisspeptin on pituitary hormone $(\mathrm{LH}, \mathrm{GH})$ secretion in goldfish. These results were confirmed later by Chang et al. (2012) and Espigares, Zanuy, and Gomez (2015).

In the present experiments we found that the changes in the levels of $\mathrm{LH}$ in the incubation media of pituitary cells (derived from untreated fish), exposed to four different concentrations of human kisspeptin: $10^{-9}$, $10^{-8}, 10^{-7}$ or $10^{-6} \mathrm{M}$ (Figs $1 \mathrm{~A}$ and $1 \mathrm{~B}$ ) were not statistically significant in comparison to the levels observed in the control incubations (without kisspeptin). Such insignificant changes occurred in both investigated seasons, i.e. at the time of gonad recrudescence (Fig 1A) and the period of natural spawning (Fig. 2A). Based on these results we could conclude that in the Prussian carp human kisspeptin is not acting directly at the level of pituitary cells. Considering the results of in vivo work by Gosiewski, Sokolowska-Mikolajczyk, Chyb, and Socha (2015), who have already demonstrated the effects of human kisspeptin on LH release in Prussian carp, we could reason that the place of kisspeptin action would have to be the brain (central action at the level of hypothalamus). However, looking for the potential interaction of kisspeptin and dopamine in the process of gonadotropin release control we repeated the above mentioned in vitro experiment according the same schedule with one difference: pituitary cells for the static incubation with kisspeptin were obtained from fish pre-treated with dopamine receptor antagonist pimozide, injected in vivo 3 hours before gland collection. The results were different - both, at the time of gonad recrudescence (Fig. 1B) as well as in the period of natural spawning (Fig. 2B), kisspeptin significantly increased $\mathrm{LH}$ concentrations if compared with control incubations. In case of recrudescence period only two concentrations of kisspeptin were stimulatory: $10^{-9}$ and $10^{-7} \mathrm{M}$ (Fig. 1B), but at the spawning period all of them were equally potent in the stimulation of LH release to the medium (Fig. 2B). These results demonstrate that the removal or the reduction of dopamine inhibitory tone in vivo by pimozide, greatly facilitates the direct action of kisspeptin on pituitary gonadotrophs resulting in increase of LH levels secreted by these cells to the incubation medium. It is possible that temporary 

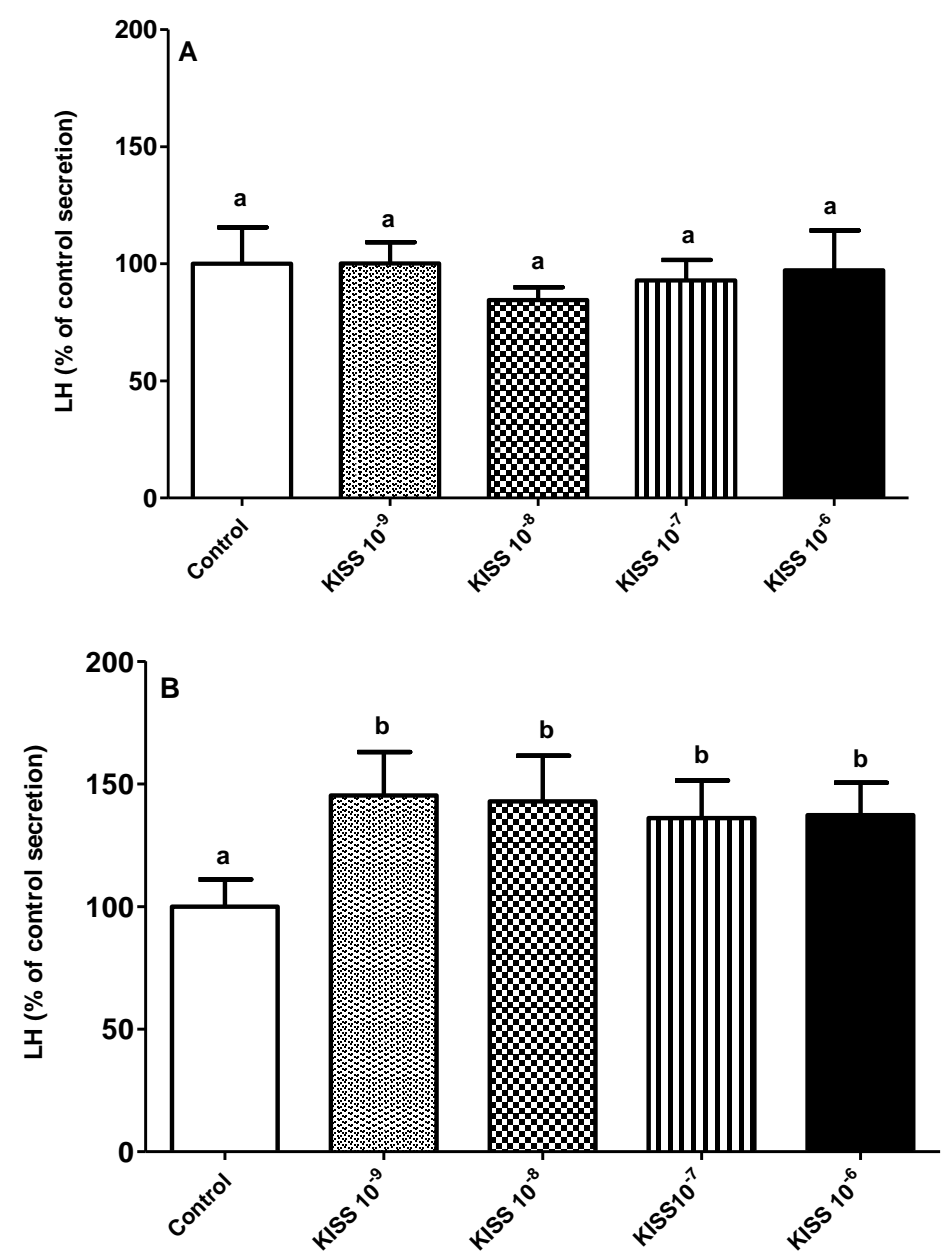

Figure 2. Percentage of control LH secretion from Prussian carp female pituitary cells harvested at the spawning season and incubated for $24 \mathrm{~h}$ with human kisspeptin at 10-9, 10-8, 10-7 or 10-6 M. (A) pituitary cells of control fish, (B) pituitary cells of fish pretreated with pimozide - a dopamine receptor antagonist 3 hours before cell harvesting. Bars represent means \pm SEM. Different letters of the alphabet identify significant differences between groups ( $P<0.05$; Mann-Whitney U-test with Bonferroni correction). Data presented on the graphs (mean percentage of LH levels \pm SEM) come from two independent experiments.

reduced inhibitory tone of dopamine up-regulates the number of kisspeptin receptors on gonadotropic cells in the pituitary. This is rather a speculative theory, because we did not measure the kisspeptin receptor number, however such a phenomenon may take place, as KISS1r mRNA expression have been reported in the pituitary of the rat (Richard, Galmiche, Corvaisier, Caraty, \& Kottler, 2008) and human (Ohtaki et al., 2001). Also Yang et al. (2010) presented evidence for KISS1r expression in goldfish somatotrophs, lactotrophs and gonadotrophs and direct action at the pituitary level to induce pituitary hormone secretion and gene expression in goldfish. If kisspeptin receptors are present in fish pituitary, the process of their up- or down-regulation is also possible and may depend on the strength of dopamine action exerted on LH release, changing with the season (external factors) and the state of gonad maturity.

In already mentioned in vivo experiments on Prussian carp (Gosiewski et al. 2015) pimozide alone significantly increased LH release in fish at the time of gonad recrudescence as well as at the spawning period and the combined treatment with pimozide and human kisspeptin caused significantly higher $\mathrm{LH}$ release in recrudescent fish than did pimozide alone, demonstrating the potentiating effects of kisspeptin on pimozide action. These results fit well with the in vitro data of the present paper and let us suggest that both, dopamine and kisspeptin, participate in the process of gonadoliberin and gonadotropin release in Prussian carp integrating hormonal and environmental signals. Dopamine seems to dominate kisspeptin, which stronger or weaker stimulates gonadoliberin or gonadotropin secretion depending on the dopamine inhibitory tone associated with current environmental conditions (suitable or not for reproduction). Seasonality of kisspeptin system activity in fish is confirmed by Migaud, Ismail, Cowan, \& Davie, (2012) and Alvarado, Carrillo, \& Felip, (2013) who presented sex-dependent differences in the dynamic of kisspeptin and kisspeptin receptor gene expression in the hypothalamus of European sea bass during gonad maturation cycle.

Kisspeptin influence on $\mathrm{GnRH} / \mathrm{LH}$ release in fish (measured by blood LH levels) is present throughout the 
sexual cycle, but it is the more pronounced when the inhibitory dopamine effect gets weaker. This conclusion is important for understanding the whole complexicity of stimulating and inhibiting factors influencing $\mathrm{LH}$ release in fish. This is especially visible in the light of the results showing that in fish, besides dopamine, acting as a gonadotropin release inhibiting factor the presence of another hormone - the gonadotropin inhibitory hormone $(\mathrm{GnIH})$, negatively regulating $\mathrm{LH}$ release in teleost is confirmed (Sawada et al., 2002; Zhang et al., 2010; Ogawa \& Parhar, 2014). Only consideration of the multifactorial regulation of sexual maturation and reproduction in fish (stimulatory and inhibitory), may provide an important tool for controlling these processes in aquaculture.

\section{Acknowledgement}

Research was financed by the Ministry of Science and Higher Education of the Republic of Poland (National Science Centre grant number DEC2011/01/N/NZ4/01159 and DS-3202/KliR)

\section{References}

Alvarado, M.V., Carrillo, M., \& Felip, A. (2013). Expression of kisspeptins and their receptors, gnrh-1/gnrhr-II-1a and gonadotropin genes in the brain of adult male and female European sea bass during different gonadal stages. General and Comparative Endocrinology, 187, 104-116. http://dx.doi.org/10.1016/j.ygcen.2013.03.030

Arabaci, M., \& Sari, M. (2004). Induction of ovulation in endemic pearl mullet (Chalcalburnus tarichi), living in the highly alkaline Lake Van, using GnRHa ([d-Ser(tBu) ${ }^{6}$, Pro $^{9}-$ Net]-GnRH) combined with haloperidol. Aquaculture, 238(1-4), 529-535. http://dx.doi.org/10.1016/j.aquaculture.2004.05.004

Beck, B.H., Fulle, S.A., Peatman, E., McEntire, M.E., Darwish, A., \& Freeman, D.W. (2012) .Chronic exogenous kisspeptin administration accelerates gonadal development in basses of the genus Morone. Comparative Biochemistry and Physiology, 162, 265273. http://dx.doi.org/10.1016/j.cbpa.2012.03.019

Brzuska, E. (2001). Artificial spawning of European catfish Silurus glanis L.: differences between propagation results after stimulation of ovulation with carp pituitary and Ovopel. Aquaculture Research, 32(1), 11-19. http://dx.doi.org/10.1111/j.1365-2109.2001.00520.x

Chang, J.P., Mar, A., Wlasichuk, M., \& Wong, A.O. (2012). Kisspeptin-1 directly stimulates $\mathrm{LH}$ and $\mathrm{GH}$ secretion from goldfish pituitary cells in a $\mathrm{Ca}(2+)$-dependent manner. General and Comparative Endocrinology, 179, 38-46. http://dx.doi.org/10.1016/j.ygcen.2012.07.028

Clarkson, J., \& Herbison, A.E. (2011). Dual phenotype kisspeptin-dopamine neurones of the rostral periventricular area of the third ventricle project to gonadotrophin-releasing hormone neurones. Journal of Neuroendocrinology, 23, 293-301. http://dx.doi.org/10.1111/j.1365-2826.2011.02107.x

Copeland, P.A., \& Thomas, P. (1989). Control of gonadotropin release in the Atlantic croaker (Micropogonias undulatus): evidence for lack of dopaminergic inhibition. General and Comparative Endocrinology, 74(3), 474-483. http://dx.doi.org/10.1016/S0016-6480(89)80045-0

Espigares, F., Zanuy, S., \& Gomez, A. (2015). Kiss2 as a regulator of $L$ and Fsh secretion via paracrine/autocrine signaling in the teleost fish European sea bass (Dicentrarchus labrax).Biology of reproduction 93(5), 114, 1-12. http://dx.doi:10.1095/biolreprod.115.131029.

Felip, S., Zanuy, S., Pineda, R., Pinilla, L., Carrillo, M., TenaSempere, M., \& Gomez, A (2009). Evidence for two distinct KiSS genes in non-placental vertebrates that encode kisspeptins with different gonadotropinreleasing activities in fish and mammals. Molecular and Cellular Endocrinology, 312, 61-71. http://dx.doi.org/10.1016/j.mce.2008.11.017

Goodman, R.L., Maltby, M.J., Millar, R.P., Hileman, S.M., Nestor, C.C., Whiteb, B., ... Lehman, M.N. (2012). Evidence that dopamine acts via kisspeptin to hold $\mathrm{GnRH}$ pulse frequency in check in anestrous ewes. Endocrinology, 153, 5918-5927. http://dx.doi.org/10.1210/en.2012-1611

Gosiewski, G., Sokolowska-Mikolajczyk, M., Chyb, J., \& Socha, M. (2015). Preliminary results on the influence of human kisspeptin on LH secretion in Prussian carp (Carassius gibelio) female at the stage of ovarian recrudescence and spawning season. Folia Biologica, 65, 25-33. http://dx.doi.org/10.3409/fb63_1.25

Gutiérrez-Pascual, E., Martínez-Fuentes, A.J., Pinilla, L., TenaSempere, M., Malagón, M.M., \& Castaño, J.P. (2007). Direct pituitary effects of kisspeptin: activation of gonadotrophs and somatotrophs and stimulation of luteinising hormone and growth hormone secretion. Journal of Neuroendocrinology 19(7), 521-530. http://dx.doi.org/10.1111/j.1365-2826.2007.01558.x

Kah, O., Pontet, A., Nunez Rodriguez, J., Calas, A., \& Breton, B. (1989a). Development of an enzyme-linked immunosorbent assay for goldfish gonadotropin. Biology of Reproduction, 41, 68-73. doi: org/10.1095/biolreprod41.1.68

Kah, O., Pontet, A., Danger, J.M., Dubourg, P., Pelletier, G., Vaudry, H., \& Calas, A, (1989b). Characterization, cerebral distribution and gonadotropin release activity of neuropeptide $Y$ (NPY) in the goldfish. Fish Physiology and Biochemistry, 7(1-6), 69-76. http://dx.doi.org/ 10.1007/BF00004691

Kah, O., Trudeau, V.L., Sloley, B.D., Chang, J.P., Dubourg, P., Yu, K.L., \& Peter, R.E. (1992). Influence of GABA on gonadotrophin release in the goldfish. Neuroendocrinology, 55(4), 396-404. http://dx.doi.org/10.1159/000126150

Kitahashi, T., Ogawa, S., Parhar, I.S. (2009). Cloning and expression of kiss2 in the zebrafish and medaka. Endocrinology, 150, 821-831 http://dx.doi.org/10.1210/en.2008-0940

Li, S., Zhang, Y., Liu, Y., Huang, X., Huang, W., Lu, D., Zhu, P., ... Lin, H. (2009). Structural and functional multiplicity of the kisspeptin/GPR54 system in goldfish (Carassius auratus). Journal of Endocrinology, 201, 407-418. http://dx.doi.org/10.1677/JOE-09-0016

Levavi-Sivan, B., Bogerd, J., Mañanós, E.L., Gómez, A., \& Lareyre, J.J. (2010). Perspectives on fish gonadotropins and their receptors. General and Comparative Endocrinology, 165, 412-437. http://dx.doi.org/10.1016.ygcen.2009.07.01 
Mechaly, A.S., Vińas, J., \& Piferrer, F. (2009). Identification of two isoforms of the Kisspeptin-1 receptor (kiss1r) generated by alternative splicing in a modern teleost, the Senegalese sole (Solea senegalensis). Biology of Reproduction, 80 , 60-69. http://dx.doi.org/10.1095/biolreprod.108.072173

Mechaly, A.S., Vinas, J., Piferrer. F. (2013). The kisspeptin system genes in teleost fish, their structure and regulation, with particular attention to the situation in Pleuronectiformes. General and Comparative Endocrinology, 188, 258-268. http://dx.doi.org/10.1016/j.ygcen.2013.04.010

Migaud, H., Ismail, R., Cowan, M., \& Davie, A. (2012). Kisspeptin and seasonal control of reproduction in male European sea bass (Dicentrarchus labrax). General and Comparative Endocrinology, 179, 384-399. http://dx.doi.org/10.1016/j.ygcen.2012.07.033

Mikolajczyk, T., Weil, C., Epler, P., \& Breton, B. (1990). Calcium ions as a mediator in $\mathrm{GnRH}$ action on gonadotropin release in the common carp (Cyprinus carpio L.). Reproduction, Nutrition, Development, 30, 483-492. http://dx.doi.org/10.1051/rnd:19900403

Mikolajczyk, T., Chyb, J., Sokolowska-Mikolajczyk, M., Enright, W., Epler, P., Filipiak, M., \& Breton, B. (2003). Attempts to induce an LH surge and ovulation in common carp (Cyprinus carpio L.) by differential application of a potent GnRH analogue, azagly-nafarelin, under laboratory commercial hatchery and natural conditions. Aquaculture, 223(1-4), 141-157. http://dx.doi.org/10.1016/S0044-8486(03)00158-3

Mohammed, J.S., Benninghoff, A.D., Holt, G.J., \& Khan, I.A. (2007). Developmental expression of the G proteincoupled receptor 54 and three GnRH mRNAs in the teleost fish cobia. Journal of Molecular Endocrinology, 38, 235-244. http://dx.doi.org/10.1677/jme.1.20182

Mylonas, C.C., Fostier, A., \& Zanuy, S. (2010). Broodstock management and hormonal manipulations of fish reproduction. General and Comparative Endocrinology, 165(3),

516-534. http://dx.doi.org/10.1016/j.ygcen.2009.03.007

Nocillado, J.N., Levavi-Sivan, B., Carrick, F., \& Elizur, A. (2007). Temporal expression of G- protein-coupled receptor 54 (GPR54), gonadotropin-releasing hormones (GnRH), and dopamine receptor D2 (drd2) in pubertal female grey mullet, Mugil cephalus. General and Comparative Endocrinology, 150, 278-287. http://dx.doi.org/10.1016/j.ygcen.2006.09.008

Nocillado, J.N., Zohar, Y., Biran, J., Levavi-Sivan, B., \& Elizur A. (2013). Chronic kisspeptin administration stimulated gonadal development in pre-pubertal male yellowtail kingfish (Seriola lalandi; Perciformes) during the breeding and non-breeding season General and Comparative Endocrinology, 191, 168-176. http://dx.doi.org/10.1016/j.ygcen.2013.06.005

Ogawa, S., Parhar, I.S. (2013) Anatomy of the kisspeptin systems in teleosts. General and Comparative Endocrinology, 15, 169-174 http://dx.doi.org/10.1016/j.ygcen.2012.08.023

Ogawa, S., \& Parhar, I.S. (2014). Structural and functional divergence of gonadotropin-inhibitory hormone from jawless fish to mammals. Frontiers in Endocrinology (Lausanne), $\quad 5, \quad 177, \quad 1-17$. http://dx.doi.org/10.3389/fendo.2014.00177

Ohtaki T, Shintani Y, Honda S, Matsumoto H, Hori A, Kanehashi K, ... Fujino M. (2001). Metastasis suppressor gene KiSS- encodes peptide ligand of a G-protein-coupled receptor. Nature 411(6837),

613-617.

http://dx.doi.org/10.1038/35079135

Ozawa, H., Sawai, N., Iwata, K., Takumi, K., \& lijima, N. (2012). Regulation of tuberoinfundibular dopamine (TIDA) neurons by kisspeptin neurons. Journal of Nippon Medical School, 79, 168-169. http://dx.doi.org/10.1272/jnms.79.168

Parhar, I.S., Ogawa, S., \& Sakuma, Y. (2004). Laser-captured single digoxigenin-labeled neurons of gonadotropinreleasing hormone types reveal a novel $G$ protein coupled receptor (Gpr54) during maturation in cichlid fish. Endocrinology, 145, 3613-3618. http://dx.doi.org/10.1210/en.2004-0395

Peng, C., Gallin, W., Pete, R.E., Blomqvist, A.G., \& Larhammar, D. (1994). Neuropeptide-Y gene expression in the goldfish brain: distribution and regulation by ovarian steroids. Endocrinology, 134(3), 1095-1103. http://dx.doi.org/10.1210/endo.134.3.8119148

Richard, N., Corvaisier, S., Camacho, E., \& Kottler, M.L. (2009). KiSS-1 and GPR54 at the pituitary level: overview and recent insights. Peptides, 30, 123-129. http://dx.doi.org/10.1016/j.peptides.2008.09.015

Richard, N., Galmiche, G., Corvaisier, S., Caraty, A., \& Kottler, M.L. (2008). KiSS-1 and GPR54 genes are co-expressed in rat gonadotrophs and differentially regulated in vivo by oestradiol and gonadotrophin-releasing hormone. Journal of Neuroendocrinology 20(3), 381-393. http://dx.doi.org/10.1111/j.1365-2826.2008.01653.x

Sawada, K., Ukena, K., Satake, H., Iwakoshi, E., Minakata, H., \& Tsutsui, K. (2002). Novel fish hypothalamic neuropeptide. European Journal of Biochemistry 269, 6000-6008. http://dx.doi.org/10.1046/j.14321033.2002.03351.x

Selvaraj, S., Kitano, H., Fujinaga, Y., Ohga, H., Yoneda, M., Yamaguchi, A., ... \& Matsuyama, M. (2010). Molecular characterization, tissue distribution, and mRNA expression profiles of two Kiss genes in the adult male and female chub mackerel (Scomber japonicus) during different gonadal stages. General and Comparative Endocrinology, 169: 28-38. http://dx.doi.org/10.1016/j.ygcen.2010.07.011

Selvaraj, S., Kitano, H., Amano, M., Ohga, H., Yoneda, M., Yamaguchi, A., ... \& Matsuyama, M. (2012). Increased expression of kisspeptin and GnRH forms in the brain of scombroid fish during final ovarian maturation and ovulation. Reproductive Biology and Endocrinology, 10: 64. http://dx.doi.org/0.1186/1477-7827-10-64

Selvaraj, S., Ohga, H., Kitano, H., Nyuji, M., Yamaguchi, A., \& Matsuyama M. (2013). Peripheral administration of Kiss1 pentadecapeptide induces gonadal development in sexually immature adult scombroid fish. Zoological Science, 30(6), 446-454. http://dx.doi.org/10.2108/zsj.30.446

Shahjahan, M., Kitahashi, T., Ogawa, S., \& Parhar, S. (2013). Temperature differentially regulates the two kisspeptin systems in the brain of zebrafish. General and Comparative Endocrinology, 193, 79-85. http://dx.doi.org/10.1016/j.ygcen.2013.07.015

Smith, J.T., Clifton, D.K., \& Steiner, R.A. (2006). Regulation of the neuroendocrine reproductive axis by kisspeptinGPR54 signaling. Reproduction, 131, 623-663. http://dx.doi.org/10.1530/rep.1.00368

Sokolowska-Mikolajczyk, M., Socha, M., Szczerbik, P., \& Epler, P. (2009). The effects of ghrelin on the in vitro 
spontaneous and sGnRH-A stimulated luteinizing hormone (LH) release from the pituitary cells of common carp (Cyprinus carpio L.). Comparative Biochemistry and Physiology, A 153(4), 386-390. http://dx.doi.org/10.1016/j.cbpa.2009.03.012

Vacher, C., Mañanos, E.L., Breton, B., Marmignon, M.H., \& Saligaut, C. (2000). Modulation of pituitary dopamine D1 or D2 receptors and secretion of follicle stimulating hormone and luteinizing hormone during the annual reproductive cycle of female rainbow trout. Journal of Neuroendocrinology, 12(12), 1219-1226. http://dx.doi.org/10.1046/j.1365-2826.2000.00585.x

Vacher, C., Ferrière, F., Marmignon, M.H., Pellegrini, E., \& Saligaut, C. (2002). Dopamine D2 receptors and secretion of FSH and LH: role of sexual steroids on the pituitary of the female rainbow trout. General and Comparative Endocrinology, 127(2), 198-206. http://dx.doi.org/10.1016/S0016-6480(02)00046-1

Zhang, Y., Li, S., Liu, Y., Lu, D., Chen, H., Huang, X., ... Cheng, C.H. (2010). Structural diversity of the $\mathrm{GnIH} / \mathrm{GnIH}$ receptor system in teleost: its involvement in early development and the negative control of $\mathrm{LH}$ release. Peptides, 31(6), 1034-1043. http://dx.doi.org 10.1016/j.peptides.2010.03.003

Zmora, N., Stubblefield, J., Zulperi, Z., Biran, J., Levavi-Sivan, B., Muñoz-Cueto, J.A., \& Zohar, Y. (2012). Differential and gonad stage-dependent roles of kisspeptin1 and kisspeptin2 in reproduction in the modern teleosts, morone species. Biology of Reproduction, 86(6), 177, 1 12. http://dx.doi.org/10.1095/biolreprod.111.097667

Zohar, Y., \& Mylonas, C.C. (2001). Endocrine manipulations of spawning in cultured fish: from hormones to genes. Aquaculture, 197(1-4), 99-136. http://dx.doi.org/10.1016/S0044-8486(01)00584-1

Zohar, Y., Munoz-Cueto, J.A., Elizur, A., \& Kah. O. (2010). Neuroendocrinology of reproduction in teleost fish. General and Comparative Endocrinology, 165, 438-455. http://dx.doi.org/10.1016/j.ygcen.2009.04.017

Yaron, Z. (1995). Endocrine control of gametogenesis and spawning induction in the carp. Aquaculture, 129(1-4), 49-73. http://dx.doi.org/10.1016/0044-8486(94)00229$\mathrm{H}$

Yang, B., Jiang, Q., Chan, T., Ko, W.K., \& Wong, A.O. (2010). Goldfish kisspeptin: molecular cloning, tissue distribution of transcript expression, and stimulatory effects on prolactin, growth hormone and luteinizing hormone secretion and gene expression via direct actions at the pituitary level. General and Comparative Endocrinology, 165, 60-71. http://dx.doi.org/10.1016/j.ygcen.2009.06.001

Yu, K.L., \& Peter, R.E. (1992). Adrenergic and dopaminergic regulation of gonadotropin-releasing hormone release from goldfish preoptic-anterior hypothalamus and pituitary in vitro. General and Comparative Endocrinology, 85(1), 138-146. http://dx.doi.org/10.1016/0016-6480(92)90181-I 